\title{
Rees Quilford
}

\section{Conversations with Althusser, Bakhtin and Genette: The influence of theory on creative practice}

\begin{abstract}
This paper offers a personal reflection on how the study of creative writing within an institutional context can influence personal creative practice. It examines how engagement with a range of theoretical approaches can help evolve both writing and thinking.

Beginning with an overview of the debate within the creative writing discipline on the benefits that an awareness of critical theory provides to the practitioner, this paper provides a reflection on how exposure to Marxist, semiotic, poststructuralist, and gender theory can stimulate thorough consideration of the separation between ideas and words. Using Louis Althusser's discussion of class and personal agency in Ideology and Ideological State Apparatuses, and Mikhail Bakhtin's semiotic examination of form and ideology in Discourse in the Novel as examples, this paper speculates on the practitioner's agency in the creative process. Judith Butler's work on the performative nature of gender construction, Roland Barthes' Death of the Author, and Hélène Cixous' Three Steps on the Ladder of Writing, are cited in relation to how an engagement with the critical can encourage and influence the writing process. Gérard Genette's writing on narratology is also considered in order to speculate on the utility that an understanding of narratology provides to the practitioner. This paper concludes with a reflection on the benefits that maintaining a sense of fun provides in the pursuit of a meaningful dialogue between the critical and the poetic. It suggests that an interaction with theory can assist practitioners when reflecting on the intricacies and influences implicit in the creative process. It argues that considered engagement with theory leads to better writing.
\end{abstract}

Keywords: creative writing, Marxism, semiotics, gender theory, narratology

The decision to return to university and study creative writing was a turning point in my life. Until that time, I had just dabbled with writing. I had published a few things, completed the occasional freelance assignment, but my approach had always been a little half-hearted. Writing was always just an interesting aside. Having it that way provided a convenient safety net, it meant avoiding the risk of failure. Returning to the academy and actively identifying as a writer changed this. It meant subjecting my writing to the scrutiny of a highly educated and informed audience. It meant offering my ideas and thoughts for critique with a very real possibility that they could be found wanting. While my return to study has been daunting, the positives have far outweighed the negatives. Moving my creative practice to an academic context has provided the opportunity to refine my approach to writing. It has allowed 
me to reflect on and refine my ideas. It has increased my productivity. As beneficial as these opportunities have been, the interaction that has most influenced my writing during this time was somewhat of a surprise. An increased engagement with theory has profoundly impacted my writing. This paper offers a reflection on how an awareness of, and dialogue with, the critical can complement the poetic.

My return to university was motivated by a conscious desire to improve a specific skill set, a very different reason to my previous study. I had completed my share of tertiary training, an undergraduate degree and a Master's program, but that journey was undertaken without a great deal of thought or planning. My tertiary study had been enough to get me into the workforce, enough to land a good job. Returning to study, particularly within the creative writing discipline, did not offer obvious benefits in furthering a corporate career. Yet something nagged. I wanted to explore, engage with, and elaborate on the ideas and imaginings that constantly occupied my attention. Pursuing writing seriously and meticulously seemed to be the logical way to do that. After much reflection, I felt compelled to make a change in my life. So, well into my thirties, I turned my back on the professional career I had been building and returned to a student life. I was going to be a writer.

Until that time, my approach had echoed Paul Dawson's idea of writing as 'a placeless individual act of creation' (Dawson 1997: 70). Returning to university meant transplanting that practice into an institutional setting. It meant filtering my creative processes through seminars and workshops. That the tertiary institution I chose places great emphasis on the theoretical aspect of the discipline would also impact on my writing practice.

The benefit that a theoretical awareness provides to the practitioner has been debated within the writing community for decades. One position holds that writers should avoid analytical discourse at all costs. The American poet Susan Stewart saw no benefit in reconciling theory and practice when she wrote: 'As any working artist knows, art practice that proceeds under the shadow of theory is doomed to be mere allegory' (Stewart 2005: 15). Creative writing scholar and poet Gregory Fraser discusses the assumption that a critical consciousness fills the mind with theoretical abstractions that create distance from the drama of language and human interaction. Theory is seen to stifle creative impulse: 'It's no overstatement, then, to claim that critical theory has long been regarded in writing circles as a "dangerous supplement" to the creative imagination' (Fraser 2008: 153). The counter argument calls for a more meaningful engagement with critical theory in the study of creative writing (Harris 2009). Author, poet and academic Hazel Smith argues that 'because critical theory is an important part of literary studies, it is extremely appropriate for it to be integrated into the teaching of creative writing' (Smith 2006: 25). After a number of years spent back within the academy, I reflect on this debate. Thinking about the classes I completed, the theory I encountered and the work I have produced leads me to speculate on what impact formal study within an institutional setting, and the increased critical awareness it necessitates, can have on the creative endeavour.

As obvious as it seems, time spent within the university context helps improve technical proficiency. The requirement to regularly submit work for peer review imbues a greater appreciation of the gut-busting effort that is required to produce good writing. It also highlights the importance of diligent editing. Naively and somewhat lazily, I had approached the process of writing without thought or purpose. In my earlier conceptualisation - one I imagine is shared by many others - a writer need just settle in front of their computer, typewriter or notepad and let the words flow. A cursory reread might follow, a typo or two 
corrected, and a phrase reworked here and there. Then the piece is finished. This haphazard approach is simply inadequate when producing work for a structured academic workshop. The process of learning-through experiment in the presence of a demanding audience (Brophy 2008: 77) foregrounds the importance of careful and diligent editing. Long, lonely hours spent hunched over the twenty-fourth draft of a piece with red pen in hand does not feature in the romanticism that surrounds writing, but discipline, patience and dedication are absolute necessities to write well. Transplanting creative practice into an institutional setting emphasises this. The rigour required within an academic context requires every word to carry its own weight. Every word must justify its inclusion. In this regard, studying creative writing within an institutional context highlights the instructional value implicit in Oscar Wilde's statement, 'I have been correcting the proofs of my poems. In the morning, after hard work, I took a comma out of one sentence. [sic] In the afternoon, I put it back again' (quoted in Sherard 1906: 273).

The structured workshopping and regular deadlines that are a fundamental component of academic based creative writing courses also instil a greater awareness of the need to establish a strong writing habit. As American writer and academic David Huddle suggests, 'The major difficulty a writer must face has nothing to do with language: it is finding or making the circumstances that make writing possible' (Huddle 1991: 1). While I still battle with procrastination, the time I have spent back within the academy has taught me that a good practitioner needs to be disciplined with routine and allocating sufficient time to see an idea from concept to fruition.

An increased engagement with critical discourse is an inevitable and important aspect of studying creative writing within an institutional setting. The theoretical -isms: Modernism, Postmodernism, Feminism, Ecocriticism, Liberalism and Marxism, to mention but a few, are fundamental to the study of the liberal arts. My return to university saw me revisit many of these discourses but also allowed the opportunity to apply and reflect upon them in relation to something that I have a genuine interest in, the creative process. The act of engaging with critical discourses exposes the writer to new ideas and encourages intellectual exchange. It forces the writer to justify their artistic choices, it encourages consideration of personal bias and subjectivity, and it invites a more thorough investment in the creative process. These actions inevitably lead to better informed writing.

Combining the critical with personal creative pursuits can be confronting. It is not uncommon to emerge somewhat bewildered and indignant. But that experience stimulates reflection and encourages consideration of the biases and assumptions that inform the perspective a writer brings to their work. In my case, a workshopping experience in the early stages of my return to study led me to engage with the work of Judith Butler. Her essay 'Performative Acts and Gender Constitution: An Essay in Phenomenology and Feminist Theory' stimulates a deeper appreciation of the constructed and stylised nature of gender and sexuality. Butler sees gender as 'an identity instituted through a stylized repetition of acts' (Butler 1988: 519). She defines these acts through which gender is constituted as performative and examines what possibilities exist for the cultural transformation of gender. Reading her work, I came to realise that Virginia Woolf's statement 'That is a man's sentence' (Woolf 1998: 99) could be applied to much of the prose I had produced to that point in time. Reading and considering Butler's work motivated me to pay closer attention to the gendered perspectives and stereotypes present in my writing. As a result, I have come to appreciate that an active engagement with gender theory within the broader writing community would likely help reduce the prevalence of 
hypersexualised, marginalised and one-dimensional characters in our narratives.

An increased critical consciousness also stimulates examination of the genesis of the creative endeavour. Kevin Brophy speculates that writing is produced by 'a contest between excitement and ideas, between intellect and emotion' (2008: 76-7). I hope that my writing is a product of passion, knowledge and perception. However, my interaction with theory has led me to question what agency I actually possess in the creative process. My reading of Marxist theory has forced me to ask whether I am an active participant in the construction of meaning or whether broader ideological forces are at play.

A Marxist position submits that social class, and the ideological stance associated with that perspective, dictates what and how the practitioner writes. Within this view, the author is not an autonomous individual whose work is informed by their creative imagination. Instead, a work of art is formed by the means of its production and its social context (Barry 2002: 77). In Ideology and Ideological State Apparatuses French Marxist philosopher Louis Althusser describes repressive ideological state apparatuses - cultural institutions and the education system - that subtly secure the internal consent of citizens while providing a superficial appearance of choice (Althusser 2001: 1489-1508). He describes the existence of ideas of beliefs as:

material actions inserted into material practices governed by material rituals which are themselves defined by the material ideological apparatus from which we derive the ideas of that subject. (Althusser 2001: 1502)

Accepting this view in relation to the creative process concedes a lack of agency in the formulation of ideas. It necessitates admitting that the study of creative writing within a formal institution teaches "know-how" but in forms which ensure subjection to the ruling ideology' (Althusser 2001: 1485). Following this argument, my return to tertiary study has made me an inadvertent, yet willing, instrument of the state. Irrespective of how much credence is given to this position, engagement with Althusser's work encourages reflection on how the customs of dominant institutions influence the practice of writing. I have been forced to consider how my rural, middle class, and (predominantly) single parent upbringing, as well as my subsequent tertiary education, have influenced my writing. I have been compelled to question how this has informed the perspective from which I write, and how it manifests in my work. For example, how my upbringing has shaped my understanding and representation of alienation, isolation and loss. I believe this process of self-reflection has led to greater nuance in both thought and practice; it has stimulated an understanding of the need to be considered when exploring the intricacies of class, equality and social standing.

Russian philosopher and literary critic Mikhail Bakhtin, adopts a semiotic approach to argue that form and ideology are inseparable (Bakhtin 2001: 1190). His essay Discourse in the Novel argues that prose writing does not consist in a single, unified form but instead incorporates 'several heterogeneous stylistic unities, often located on different linguistic levels and subject to different stylistic controls' (2001: 1192). He maintains that written prose does not communicate a single voice or point of view but is heteroglot. For Bakhtin, language reveals 'the social and historical voices populating language, which provide language with its particular concrete conceptualisations' (1220).

This multiplicity of voices is a big idea to comprehend. The concept of heteroglossia challenges notions of individual linguistic creativity, as the 
author's voice is merely one amongst many. While writing may have the appearance of a single perspective, as it inevitably draws on a common language it also becomes an expression of multiple external voices, perspectives and ideologies. This complicates aspirations for originality and individual expression but rather than see it as a negative, Bakhtin suggests that a prose writer can:

make use of language without wholly giving himself up to it, he may treat it as semi-alien or completely alien to himself, while compelling language ultimately to serve all his intentions. (Bakhtin 2001: 1219)

Bakhtin's position, and indeed that of Althusser, implies an uncomfortable distance between words and ideas, yet the idea of aspiring for a mastery of language as a means through which to convey complex ideas is compelling. The work of French linguist Roland Barthes is instructional in this regard. Rejecting authorial authority as a forced projection, he instead focuses on language and narrative structure, and suggests that meaning is actively created by the reader through a process of textual analysis (Barthes 1968: 143). The importance of context in the creation of meaning is also emphasised by the French philosopher Jacques Derrida. He writes that 'there is nothing outside context' (Derrida 1988: 136), suggesting that an understanding of language, grammar, and vocabulary, as well as a knowledge of the societal and historical setting, is inevitable when engaging with any text. Barthes and Derrida's notions of collaborative meaning within a broad societal context are appealing when compared to Althusser's emphasis on state apparatuses or Bakhtin's recommendation for maintaining an active distance from language. Barthes conceived the act of writing as a multi-dimensional dialogue in which ideas drawn from diverse cultures clash and blend:

In the multiplicity of writing, everything is to be disentangled, nothing deciphered; the structure can be followed, 'run' (like the thread of a stocking) at every point and at every level, but there is nothing beneath: the space of writing is to be ranged over, not pierced; writing ceaselessly posits meaning ceaselessly to evaporate it, carrying out a systematic exemption of meaning. (Barthes 1977: 147)

Barthes emphasises structure, style and language in the creative process and aspires for a form of writing that does not seek to impose its meaning on the reader. Writing is not a process I want to distance myself from - whether it is attempting to replicate a moment, a situation or a concept, I actively attempt to embed myself in the process - but I also want to avoid being didactic, which makes Barthes and Derrida's notion of writing as a multifaceted playground for collaborative meaning making so exciting. Personally, I don't believe the act of writing is some form of liberal humanist mimesis or disinterested enquiry (Lee 2011: 8) and my interactions with the theories put forward by Barthes, Bakhtin, Derrida, and Althusser have encouraged consideration of whether language (and by connotation my writing) records reality or actively constructs it. This has led to a greater awareness that any meaning that arises from the work I produce will be jointly constructed with the reader.

Hélène Cixous' Three Steps on the Ladder of Writing is an exemplar of writing that actively foregrounds its theoretical awareness. An intimate intertextual reflection on the process of writing - or as she terms it 'the strange science of writing' (Cixous 1993: 3) - her work explores the influence of subjectivity, and challenges orthodox understandings of critical objectivity. Reflecting on how 
death, dreaming and the 'nether realms' of individual imagination can influence writing, Cixous elaborates on how the writing process affects her:

Between the writer and his or her family the question is always one of departing while remaining in full presence, of escaping, of abandon. It is both utterly banal and the thing we don't want to know or say. A writer has no children; I have no children when I write. When I write I escape myself, I uproot myself, I am a virgin; I leave from within my house and I don't return. The moment I pick up my pen - magical gesture - I forget all the people I love; an hour later they are not born and I have never known them. Yet we do return. (Cixous 1993: 21)

This uninhibited plunge into the creative act results in highly engaging writing. Cixous' prose is elegant, rich and acutely conscious of its own theoretical underpinnings. By consciously referencing the texts and discourses that have influenced her life and her work - namely, her encounters with the works of Kafka, Marina Tsvetaeva, Clarice Lispector, Ingeborg Bachmann, Thomas Bernhard, and Dostoyevsky - she engages in a dialogue that spans both language and time. Cixous practices a reflexive intertextuality (Schneider 1996: 527 ) that allows examination of the significance of writing in and on her life. In this regard, combining the critical with the poetic provides an effective tool to explore subjective experience and speculate on the broader nature of creativity.

Theory has numerous practical applications. The obvious example being how it can improve the practitioner's understanding of the mechanics and devices of narrative, something most helpful to the actual creative process. French literary theorist Gérard Genette's work on narratology is enlightening in this regard. Examining how meaning is constructed in narrative, he focuses on the nature, form and functions of storytelling (Prince 2003: 66). The remark 'show, don't tell' seems to be a standard part of the workshopping experience and Genette's discussion of the 'mimetic' or 'diegetic' nature of narrative is useful in reconciling this 'show' versus 'tell' dichotomy within the creative process. Emphasising the illusory nature of the concept of mimetic showing, he suggests that what is actually occurring is mere dramatic representation, "no narrative can "show" or "imitate" the story it tells. All it can do is tell it in a manner which is detailed, precise, "alive," and in that way gives more or less the illusion of mimesis' (Genette 1980: 163-4). For the practitioner, Genette's argument suggests that the distinction between showing and telling is somewhat of a furphy: showing can only be a way of telling. This highlights the importance of producing highly engaging prose, and of the need to use exact and evocative language to communicate ideas. It also places an emphasis on plot and the ability to shortcut where one can but also highlights the need to elaborate on scenes or themes of consequence.

Genette also discussed narrative focalisation, exploring the mechanics of pointof-view, narrative frames, and narrative levels. His discussion on frame narratives provides a good example of theoretical discussion that has practical value for the practitioner. For Genette, the events described in the embedded narrative are defined as metadiegetic while those occurring in the first narrative are diegetic or intradiegetic (Genette 1980: 228). Any intrusion by the extradiegetic narrator into the diegetic universe or by diegetic characters into a metadiegetic universe creates an effect of strangeness that is either comic or fantastic (Genette 1980: 235). This act foregrounds the constructed nature of a work and demonstrates the importance of 'a shifting but sacred frontier between two worlds, the world in which one tells, the world in which one shows' (Genette 1980: 236). I have often experimented with narrative focalisation in my writing but in a clumsy and uninformed manner. Something 
originally written in the first person was often reworked to employ third-person narration. A frame might have been added then later removed. Genette's terminology - extradiegetic intrusion, diegetic universe, etc - is unlikely to be front of mind when composing a frame narrative but a knowledge of narratology provides the practitioner with a valuable understanding of the likely affect it will have on the reader. This awareness brings a more systematic approach to the process of experimentation. At the very least, it provides the practitioner with an understanding that changing the focalisation of a narrative is likely to increase the reader's awareness of the constructed and subjective nature of their work.

An increased critical consciousness can also bring greater depth to the act of reading. Peter Barry (2002: 199) raises the possibility of a scholar who is aware of, and sensitive to, multiple critical approaches but questions whether this merely leads to blandness and superficiality. Focus seems to be the crucial point here. Meaningful engagement requires a genuine interest in a particular approach but engagement with the critical provides a unique lens through which to examine the way in which fictional (and non-fictional) worlds are constructed. This provides the practitioner a glimpse, no matter how brief, of how others see and perceive the world.

Applying Barry's concept to the creative process provides a useful context to question how a sympathy for, and awareness of, the various critical approaches impacts on the creative process. Or as Cixous asks, 'How can we proceed to burning point, reach that last hour, when we'll be able to write or say everything we have never dared say out of love and cowardice?' (1993: 48). In my case, I believe that a better developed critical awareness has brought that burning point within reach. Examining how and why I write, as well as questioning what agency I have in the creative process, has instilled a greater confidence in my writing. That process has provided me with the courage to take my writing into unfamiliar places. This essay is an example. However, it must also be acknowledged that too great a focus on the critical can undermine creative practice. Care must be taken to avoid inserting elements into a piece simply to demonstrate a level of critical awareness. As Raymond Carver wrote, 'Writers don't need tricks or gimmicks or even necessarily need to be the smartest fellows on the block. At the risk of appearing foolish, a writer sometimes needs to be able to just stand and gape at this or that thing - a sunset or an old shoe - in absolute and simple amazement' (Carver 1988: 23).

The ability to deploy useful and unassuming astonishment can be somewhat elusive. David Foster Wallace once wrote to Don DeLillo for advice. He could see that his writing was improving but he was having less fun. In desperation, he wrote, 'maybe I want a pep-talk, because I have to tell you I don't enjoy this war one bit. I think my fiction is better than it was, but writing is also less Fun than it was' (Wallace 1995). Wallace went on to discuss his struggle with dedication in writing:

As I understand your terms "discipline," "respect," and "dedication," your thoughts have confirmed my belief that what usually presents in me as a problem with Discipline is actually more a problem with Dedication. I struggle very hard with my desires both to have Fun when writing and to be Serious when writing. (Wallace 1995)

In my experience, a meaningful engagement with theoretical discourse increases the likelihood of having fun while creating serious writing. A welldeveloped critical awareness is helpful to the practitioner as it encourages 
careful reflection on the creative process. It also leads to an improved understanding of the processes and mechanisms of good storytelling.

Rather than impeding the creative process a formal engagement with theoretical discourse can encourage a more a prolific and rigorous approach to writing. This has certainly been my experience. Butler's theoretical writing on gender forced me to confront, justify and address some of the biases present in my writing. My reading of Bakhtin and Althusser led me to question my agency in the creative process and provoked thorough consideration of the separation between ideas and words. My interaction with the work of Barthes, Derrida, and Cixous encouraged thorough reflection on the importance that language plays in my journey to and through writing.

The resonance and usefulness of critical theory will vary depending on the individual but a meaningful engagement with theoretical discourse can be extremely useful to the creative process. In addition to stimulating curiosity, it leads to a heightened awareness of the intricacies and influences implicit in the act of writing. In my experience, a considered engagement with the critical provides the practitioner a framework to better express their views, ideas and aspirations.

\section{Works Cited}

Althusser, L 2001 'Excerpt from Ideology and Ideological State Apparatuses', in VB Leitch (ed) The Norton anthology of theory and criticism, WW Norton \& Company, New York: 14831509 return to text

Bakhtin, M 2001 'Excerpt from Discourse in the Novel', in VB Leitch (ed) The Norton anthology of theory and criticism, WW Norton \& Company, New York: 1190-1220 return to text

Barry, P 2002 Beginning theory (2nd edn), Manchester University Press, Manchester return to text

Barthes, R 1977 'The Death of the Author', in Image Music Text: Essays selected and translated by Stephen Heath, Fontana Press, London: 142-148 return to text

Brophy, K 2008 'Workshopping the Workshop and Teaching the Unteachable', in G Harper \& J Kroll (eds) Creative Writing Studies: Practice, Research and Pedagogy,Multilingual Matters, Clevedon: $75-87$ return to text

Butler, J 1988 'Performative Acts and Gender Constitution: An Essay in Phenomenology and Feminist Theory', Theatre Journal 40, 4: 519-531 return to text

Carver, R 1988 'On Writing’, in Fires: Essays, Poems, Stories, Vintage Books, London: 22-27 return to text

Cixous, H 1993 Three steps on the ladder of writing, trans S Cornell \& S Sellers, Columbia University Press, New York return to text

Dawson, P 1997 'The Function of Critical Theory in Tertiary Creative Writing Programmes', Southern Review 30, 1: 70-80 return to text

Derrida, J 1988 Limited Inc, Northwestern University Press, Evanston return to text Fraser, G 2008 ‘A Translator's Tale’, in G Harper \& J Kroll (eds) Creative Writing Studies: Practice, Research and Pedagogy,Multilingual Matters, Clevedon: 152-64 return to text

Genette, G 1980 Narrative Discourse, Basil Blackwell, Oxford return to text

Harris, M 2009 'Escaping the tractor beam of literary theory: notes towards appropriate theories of creative writing - and some arguments against the inappropriate ones', TEXT 13, 2 
(October): http://www.textjournal.com.au/oct09/harris.htm (accessed 3 September 2016) return to text

Huddle, D 1991 The Writing Habit, University Press of New England, Hanover return to text

Lee, C 2011 Our very own adventure: towards a poetics of the short story, Melbourne University Publishing, Carlton Vic return to text

Prince, G 2003 Dictionary of Narratology, University of Nebraska Press, Lincoln return to text

Schneider, J 1996 'Book review: Cixous, Hélène. Three Steps on the Ladder of Writing', Studies in Twentieth \& Twenty-First Century Literature 20, 2: 526-8 return to text

Sherard, R 1906 The Life of Oscar Wilde, Mitchell Kennerley, New York return to text

Smith, H 2006 'Emerging from the experiment: a systematic methodology for creative writing teaching', New writing: The international journal for the practice and theory of creative writing 3,1 : 17-34 return to text

Stewart, S 2005 The Open Studio: Essays on Art and Aesthetics, University of Chicago Press, Chicago return to text

Wallace, D Foster 1995 I don't enjoy this war one bit: http://www.lettersofnote.com/2012/02/idont-enjoy-this-war-one-bit.html (accessed 12 May 2015) return to text

Woolf, V 1998 A Room of One's Own: And, Three Guineas, Oxford University Press, Oxford return to text

Rees Quilford is a Victorian based writer. He completed a Postgraduate Diploma in Creative Writing at the University of Melbourne in 2013 and has since joined the non/fictionLab of the School of Media and Communication at RMIT University as a PhD candidate. His writing interests include creative non-fiction, interactive storytelling, short story and screenplay.

\section{TEXT}

Vol 20 No 2 October 2016

http://www.textjournal.com.au

General Editor: Nigel Krauth. Editors: Kevin Brophy \& Enza Gandolfo text@textjournal.com.au 